Supporting Information

\title{
Postsynthetic Modification of Metal-Organic Frameworks by Vapor-Phase Grafting
}

Siyi Rong, Shizheng Chen, Pengcheng Su, Huiyu Tang, Miaomiao Jia, Yan Xia, and Wanbin Li*

Guangdong Key Laboratory of Environmental Pollution and Health, School of Environment, Jinan University, Guangzhou 511443, P.R. China

Total number of pages: 23

Total number of Figures: 13

Total number of Tables: 5

Total number of references: 7 


\section{Experimental}

\section{Preparation of $\mathrm{NH}_{2}-\mathrm{UiO}-66$}

The $\mathrm{NH}_{2}$-UiO-66 powder was synthesized by typical solvothermal method. Zirconium chloride (0.48 g) and 2-aminoterephthalic acid $(0.37 \mathrm{~g})$ were dissolved in $\mathrm{N}$, $\mathrm{N}$-dimethylformamide $(40 \mathrm{~mL})$ and deionized water $(0.19 \mathrm{~mL})$ by stirring and ultrasonic treatment. The homogeneous solution was transferred into a Teflon-lined stain less steel autoclave and subjected to thermal treatment at $120{ }^{\circ} \mathrm{C}$ for $24 \mathrm{~h}$. After crystallization, the $\mathrm{NH}_{2}$-UiO-66 power was isolated by centrifugation and purified with $\mathrm{N}$, $\mathrm{N}$-dimethylformamide and methanol.

\section{Vapor-phase grafting of $\mathrm{NH}_{2}-\mathrm{UiO}-66$}

For postsynthetic modification, trimesoyl chloride (TMC, $0.10 \mathrm{~g})$ and $\mathrm{NH}_{2}-\mathrm{UiO}-66(0.10 \mathrm{~g})$ powders were placed in one Teflon-lined stain less steel autoclave but without direct contact. For vapor-phase grafting, the autoclave was thermally treated at $60{ }^{\circ} \mathrm{C}$ for different times of 6 , 12, 24, and $48 \mathrm{~h}$. After grafting, for hydrolysis of unreacted $-\mathrm{COCl}$, the modified $\mathrm{NH}_{2}$-UiO-66 powder was immersed in water at $50{ }^{\circ} \mathrm{C}$ for $12 \mathrm{~h}$. To remove the unreacted molecules, the prepared $\mathrm{NH}_{2}-\mathrm{UiO}-66-\mathrm{VG}$ power was washed with methanol and deionized water for several times.

\section{Fluoride removal}

For adsorption kinetic, the MOF powder $(0.05 \mathrm{~g})$ was dispersed in sodium fluoride solution $(100 \mathrm{~mL})$ with fluoride concentration of $100 \mathrm{ppm}$. The mixture was stirred at room temperature for certain time for sampling. The sample was filtrated by using microfiltration 
membranes with pore of $0.45 \mathrm{um}$. The fluoride concentration was measured by using fluoride electrode analyzer. For better measurement, the sample was diluted by deionized water and total ionic strength adjustment buffer (TISAB), which was prepared by trisodium citrate dihydrate, sodium nitrate, and hydrochloric acid. For adsorption isotherm, the MOF powder $(0.01 \mathrm{~g})$ was dispersed in sodium fluoride solution $(20 \mathrm{~mL})$ with different concentrations from $5 \mathrm{ppm}$ to $100 \mathrm{ppm}$. After adsorption for $12 \mathrm{~h}$, the concentration of the solution was measured to calculate the adsorption capacity.

\section{Characterization}

The chemical structure of the prepared MOF powders was analyzed by using Fourier transform infrared spectrophotometer (FTIR, ATR, IRTracer-100, Shimadzu Co.) with mode of transmittance, apodization of Happ-Genzel, and resolution of $4 \mathrm{~cm}^{-1}$. The sample was prepared by compression with potassium bromide. X-ray photoelectron spectrophotometer (XPS, RBD upgraded PHI-5000C ESCA system, Perkin Elmer) with an incident radiation of monochromatic $\mathrm{MgK} \alpha \mathrm{X}$-rays $(\mathrm{h}=1253.6 \mathrm{eV})$ at $250 \mathrm{~W}$ was employed to study the chemical binding state of the prepared MOF powders. The sample was purified at $423 \mathrm{~K}$ and vacuum for $8 \mathrm{~h}$ before measurement. The obtained data were fitted by the XPSPEAK software and the $\mathrm{C}-\mathrm{C} / \mathrm{C}-\mathrm{H} / \mathrm{C}=\mathrm{C}$ was fitted at $284.5 \mathrm{eV}$. The proton nuclear magnetic resonance characterization was conducted by using an NMR apparatus $\left({ }^{1} \mathrm{H}\right.$ NMR, Bruker., Ascend TM 400.) The sample was digested by NaOD and D2O before characterization. The crystalline structure of the prepared MOF powders was studied by X-ray diffraction (XRD, D2 PHASER, Bruker Co.) with $\mathrm{CuK} \alpha$ radiation $(\lambda=0.154056 \mathrm{~nm})$ at $30 \mathrm{kV}$ and $10 \mathrm{~mA}$. The sample was 
scanned using scan speed of $0.2 \mathrm{~s}$ per step and step size of $0.01^{\circ}$. For investigating the porous properties of the prepared MOF powders, $\mathrm{N}_{2}$ adsorption-desorption isotherms were collected at $77 \mathrm{~K}$ by using a physisorption analyzer (Autosorb iQ Station 1, Quantachrome Co.). Before measurement, the sample was degassed at $423 \mathrm{~K}$ and vacuum for $8 \mathrm{~h}$. The pore size distribution was analyzed on the basis of the Non-Local Density Functional Theory (NLDFT) method with a slit-shaped/cylindrical pore model. $\mathrm{N}_{2}, \mathrm{CO}_{2}, \mathrm{CH}_{4}$ adsorption-desorption experiments were performed at $298 \mathrm{~K}$ by using the physisorption analyzer (Autosorb iQ Station 1, Quantachrome Co.). The sample was degassed to remove the guest molecules at $423 \mathrm{~K}$ for $8 \mathrm{~h}$. The thermogravimetric (TGA2, Mettler Toledo) curve of $\mathrm{NH}_{2}$-UiO-66-VG was collected in $\mathrm{N}_{2}$ atmosphere with a heating rate of $10{ }^{\circ} \mathrm{C} \mathrm{min}-1$ and a range from 25 to 800 ${ }^{\circ} \mathrm{C}$. 

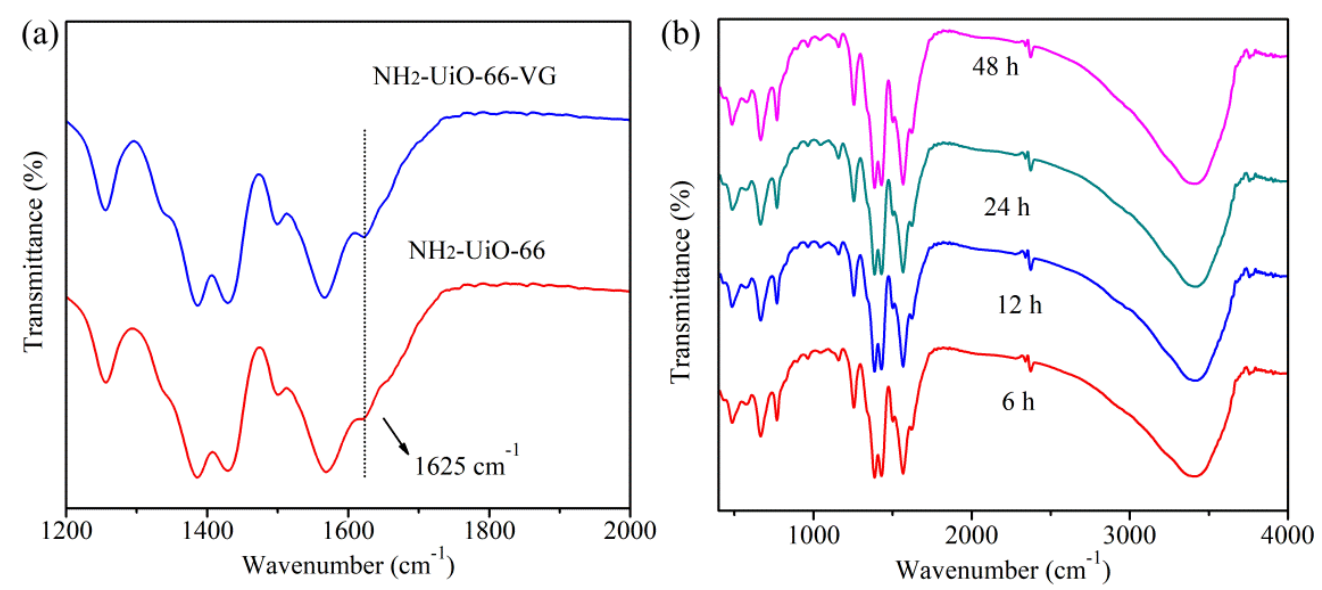

Figure S1. (a) Magnified FTIR spectra of $\mathrm{NH}_{2}-\mathrm{UiO}-66$ and $\mathrm{NH}_{2}-\mathrm{UiO}-66-\mathrm{VG}$. (b) FTIR spectra of $\mathrm{NH}_{2}-\mathrm{UiO}-66-\mathrm{VG}$ with different exposure times. 
(a)

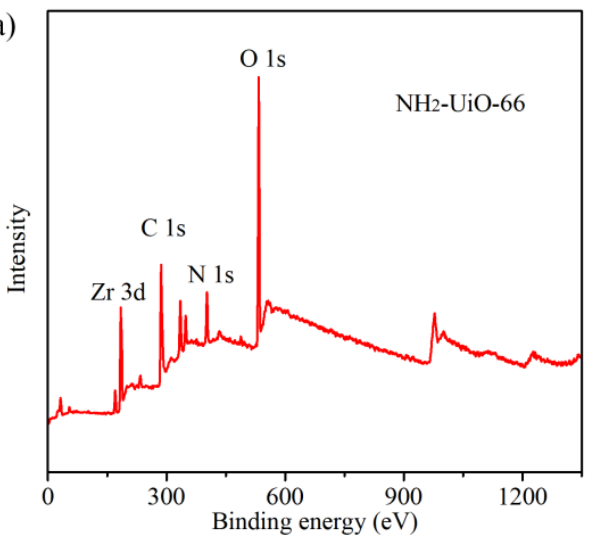

(c)

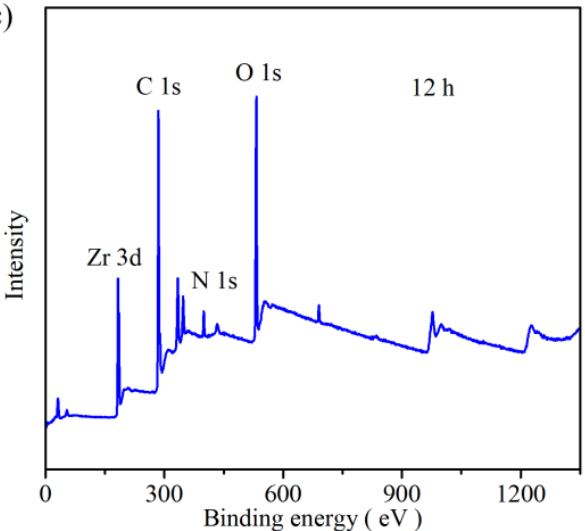

(e)

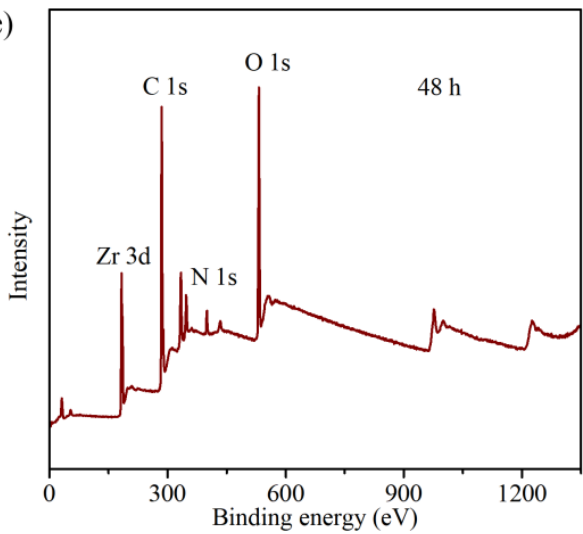

(b)

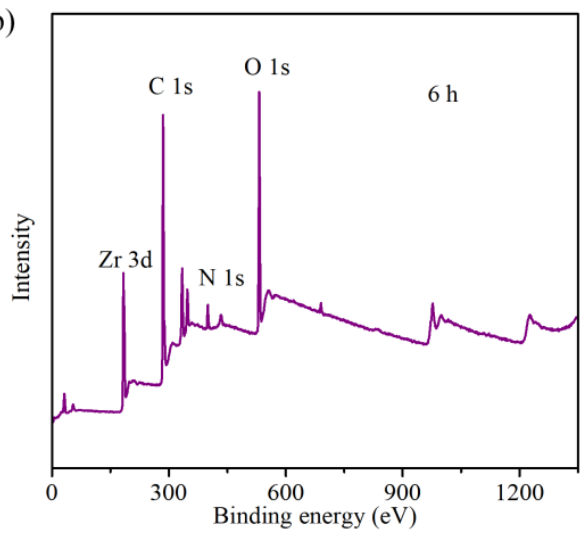

(d)

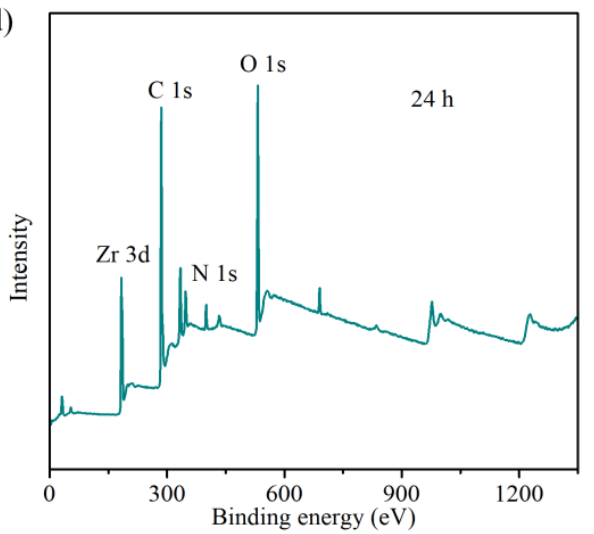

Figure S2. XPS spectra of (a) $\mathrm{NH}_{2}-\mathrm{UiO}-66$ and $\mathrm{NH}_{2}-\mathrm{UiO}-66-\mathrm{VG}$ with exposure times of (b) $6 \mathrm{~h}$, (c) $12 \mathrm{~h}$, (d) $24 \mathrm{~h}$, and (e) $48 \mathrm{~h}$. 

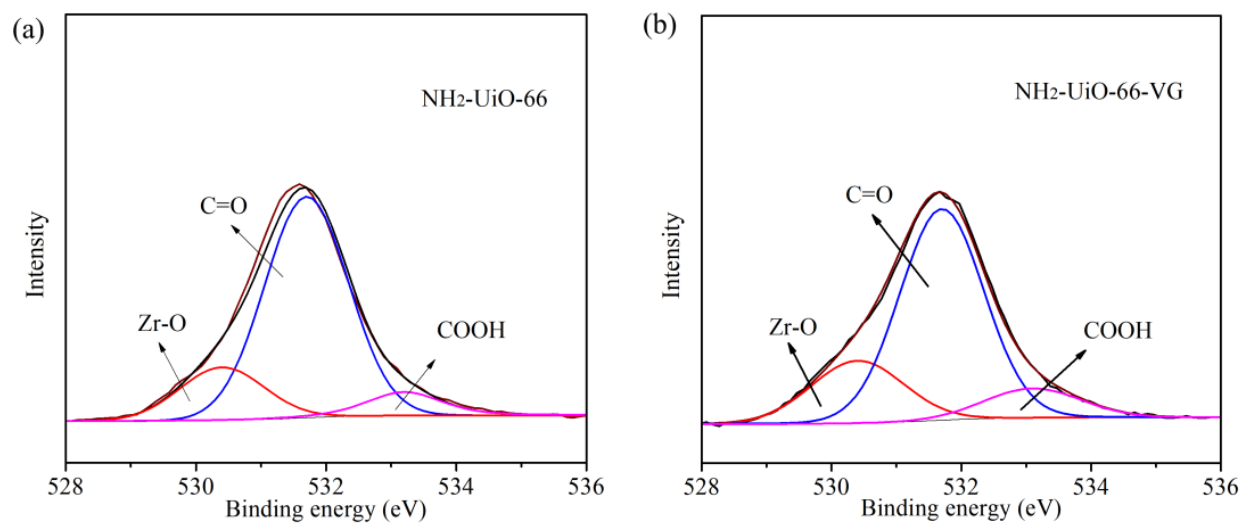

Figure S3. High-resolution O 1s XPS spectra of (a) $\mathrm{NH}_{2}$-UiO-66 and (b) $\mathrm{NH}_{2}$-UiO-66-VG. 
(a)

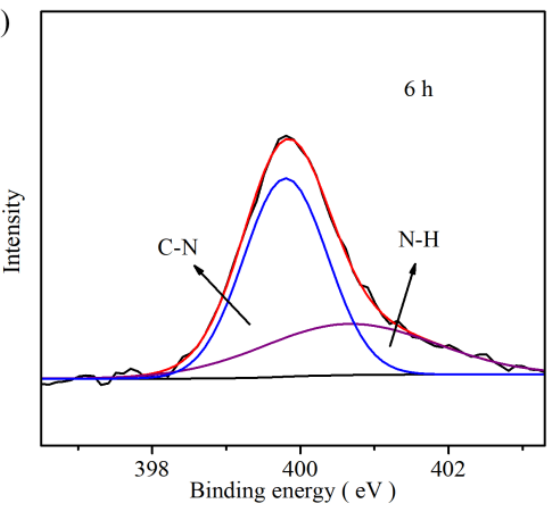

(c)

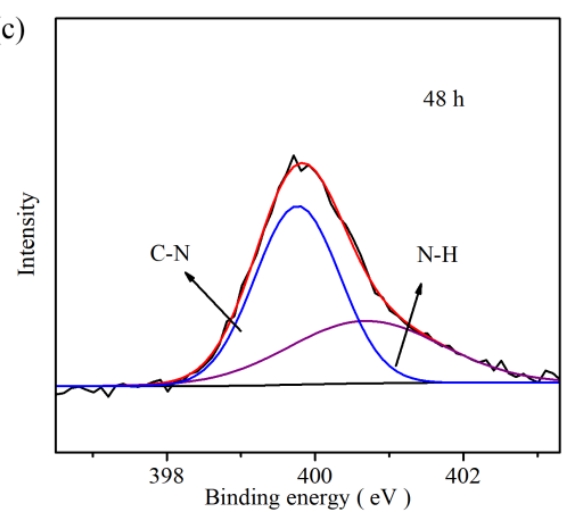

(b)

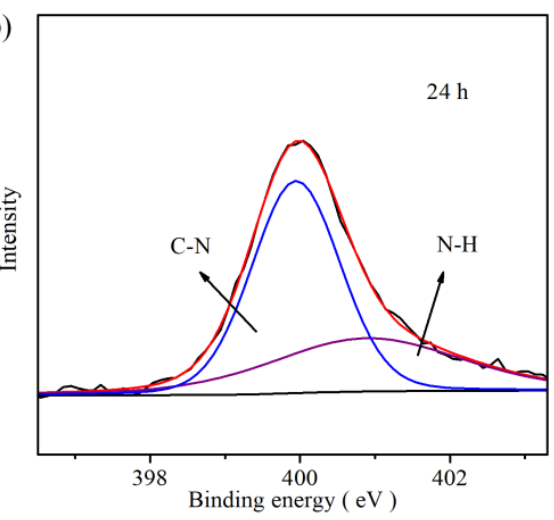

Figure S4. High-resolution N 1s XPS spectra of $\mathrm{NH}_{2}-\mathrm{UiO}-66-\mathrm{VG}$ with exposure times of (a) $6 \mathrm{~h}$, (b) $24 \mathrm{~h}$, and (c) $48 \mathrm{~h}$. 


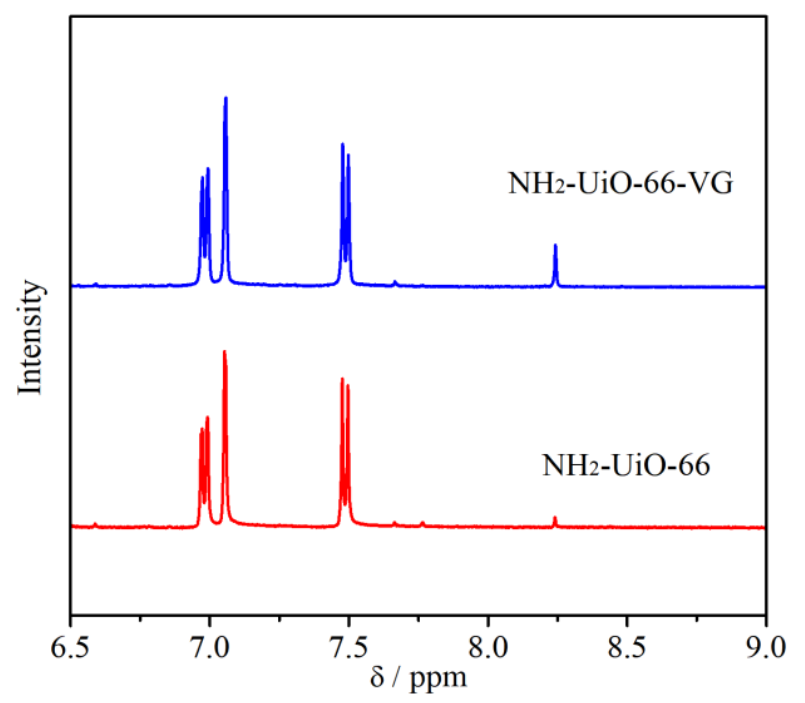

Figure S5. ${ }^{1} \mathrm{H}$ NMR spectra of $\mathrm{NH}_{2}-\mathrm{UiO}-66$ and $\mathrm{NH}_{2}-\mathrm{UiO}-66-\mathrm{VG}$. 


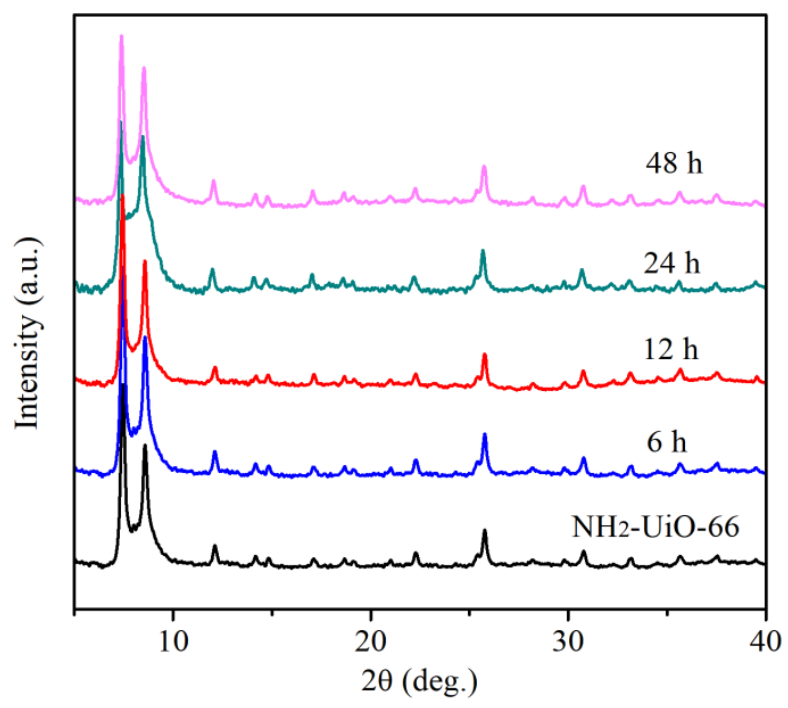

Figure S6. XRD patterns of $\mathrm{NH}_{2}-\mathrm{UiO}-66-\mathrm{VG}$ with different exposure times. 


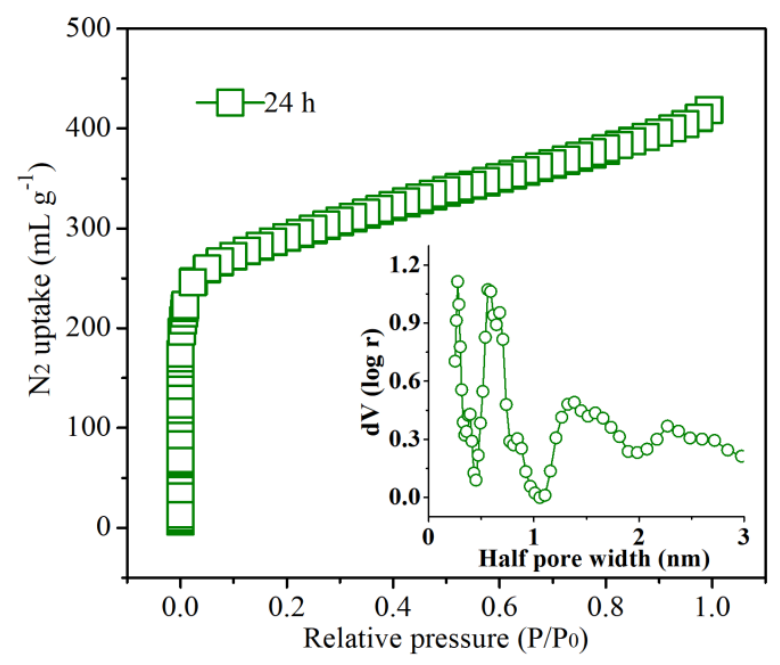

Figure S7. $\mathrm{N}_{2}$ adsorption-desorption isotherms and pore distribution of $\mathrm{NH}_{2}-\mathrm{UiO}-66-\mathrm{VG}$ with exposure time of $24 \mathrm{~h}$. 
(a)

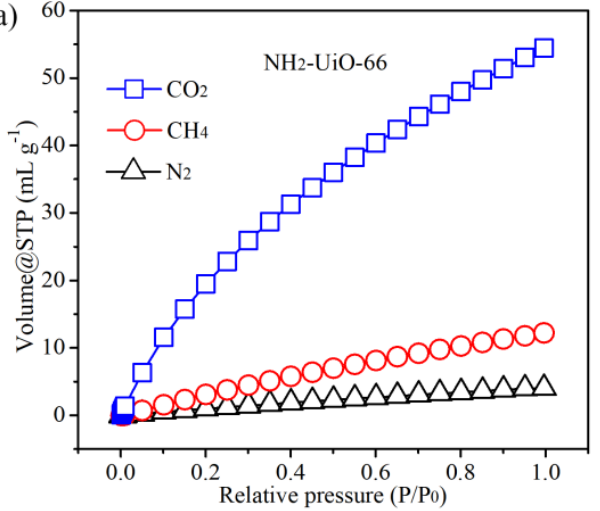

(c)
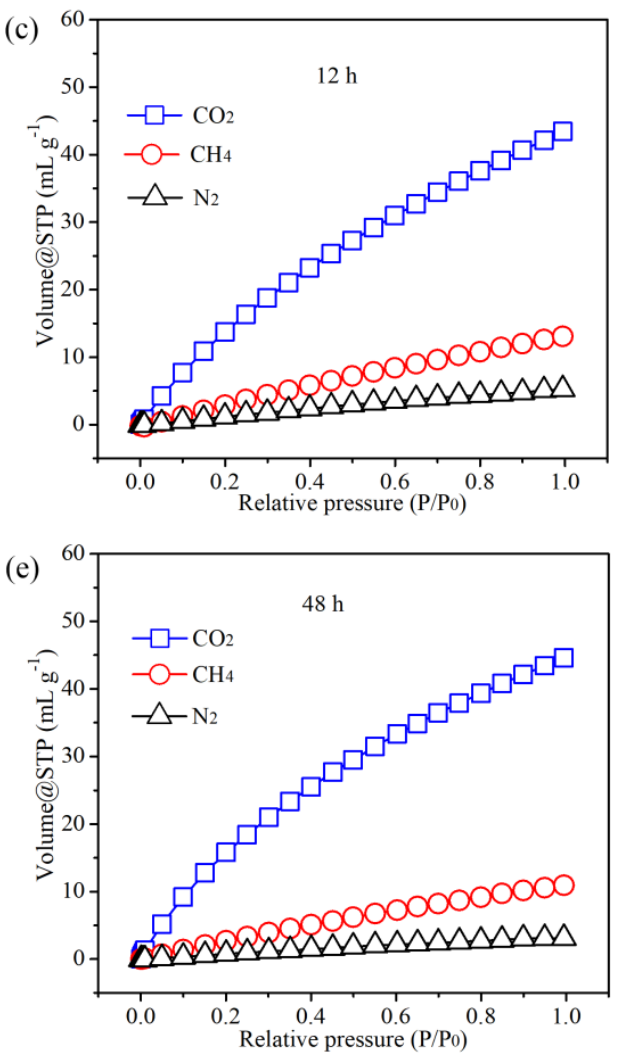
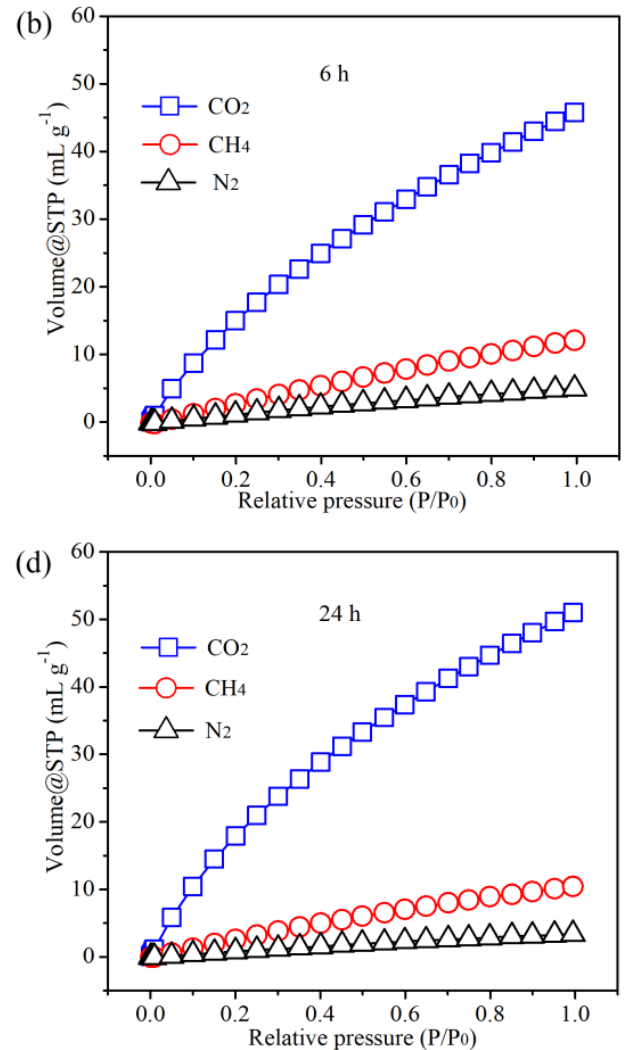

Figure S8. Gas adsorption isotherms of (a) $\mathrm{NH}_{2}-\mathrm{UiO}-66$ and $\mathrm{NH}_{2}-\mathrm{UiO}-66-\mathrm{VG}$ with exposure times of (b) $6 \mathrm{~h},(\mathrm{c}) 12 \mathrm{~h},(\mathrm{~d}) 24 \mathrm{~h}$, and (e) $48 \mathrm{~h}$. 
(a)

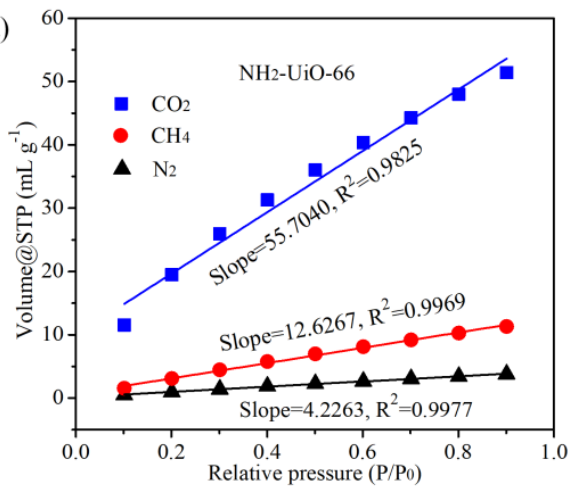

(c)

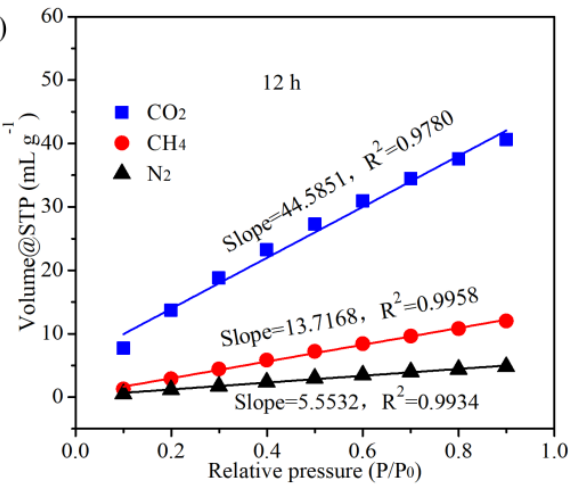

(e)

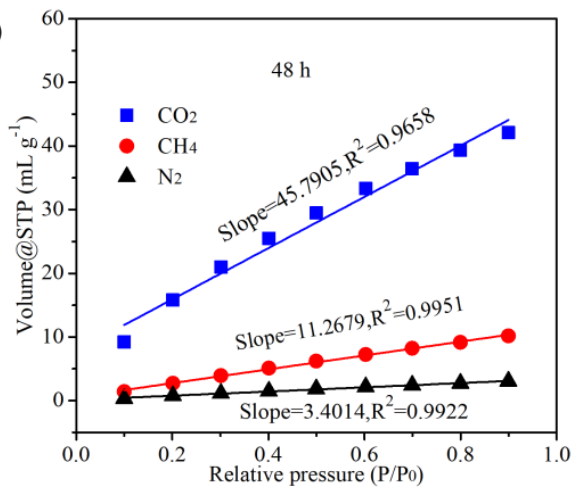

(b)

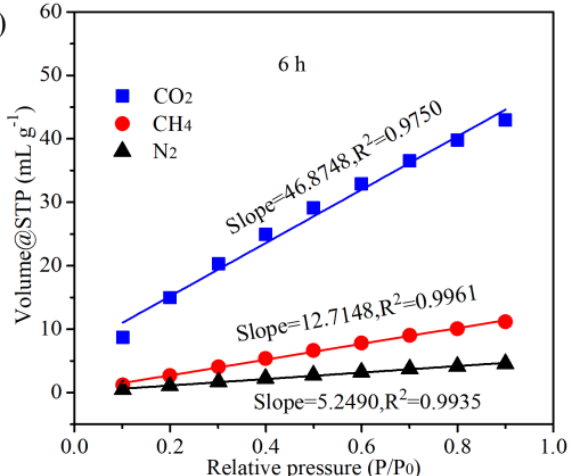

(d)

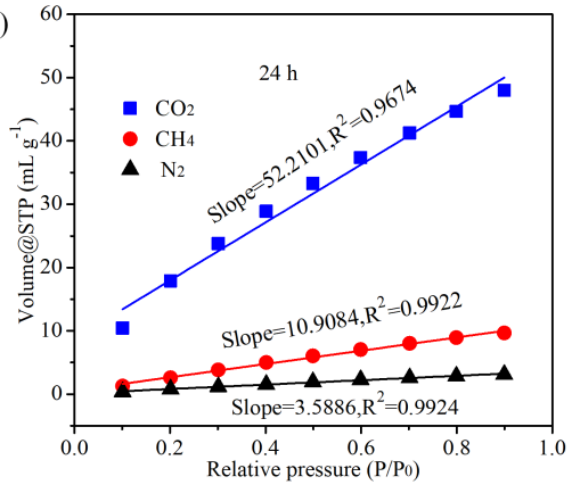

Figure S9. Linear fitting of gas uptake data of (a) $\mathrm{NH}_{2}-\mathrm{UiO}-66$ and $\mathrm{NH}_{2}-\mathrm{UiO}-66-\mathrm{VG}$ with exposure times of (b) $6 \mathrm{~h}$, (c) $12 \mathrm{~h}$, (d) $24 \mathrm{~h}$, and (e) $48 \mathrm{~h}$ based on Henry's Law. ${ }^{1}$

Henry's law coefficient $\left(K_{H}\right)$ is calculated by following equation.

$K_{H}=\frac{d n}{d p}(1)$

Henry's law selectivity is calculated by following equation:

$S_{i, j}=\frac{K_{H, i}}{K_{H, j}}$

Where $K_{H, i}$ and $K_{H, j}$ are Henry's law coefficients of pure $i$ and $j$ gases, respectively. 


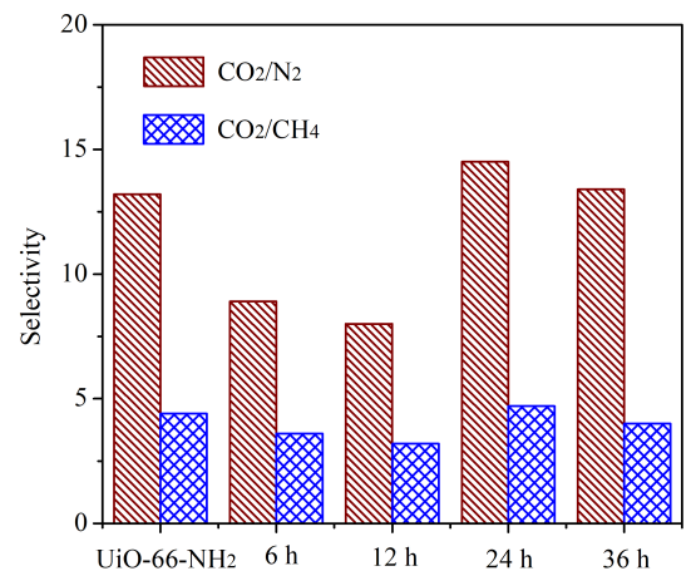

Figure S10. $\mathrm{CO}_{2} / \mathrm{N}_{2}$ and $\mathrm{CO}_{2} / \mathrm{CH}_{4}$ selectivity of $\mathrm{NH}_{2}-\mathrm{UiO}-66$ and $\mathrm{NH}_{2}-\mathrm{UiO}-66-\mathrm{VG}$ with different exposure times. 


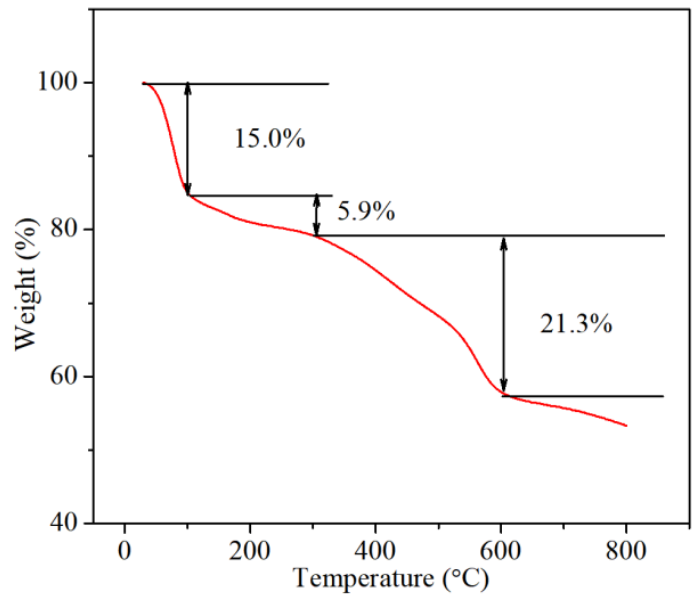

Figure S11. Thermogravimetric curve of $\mathrm{NH}_{2}-\mathrm{UiO}-66-\mathrm{VG}$. 

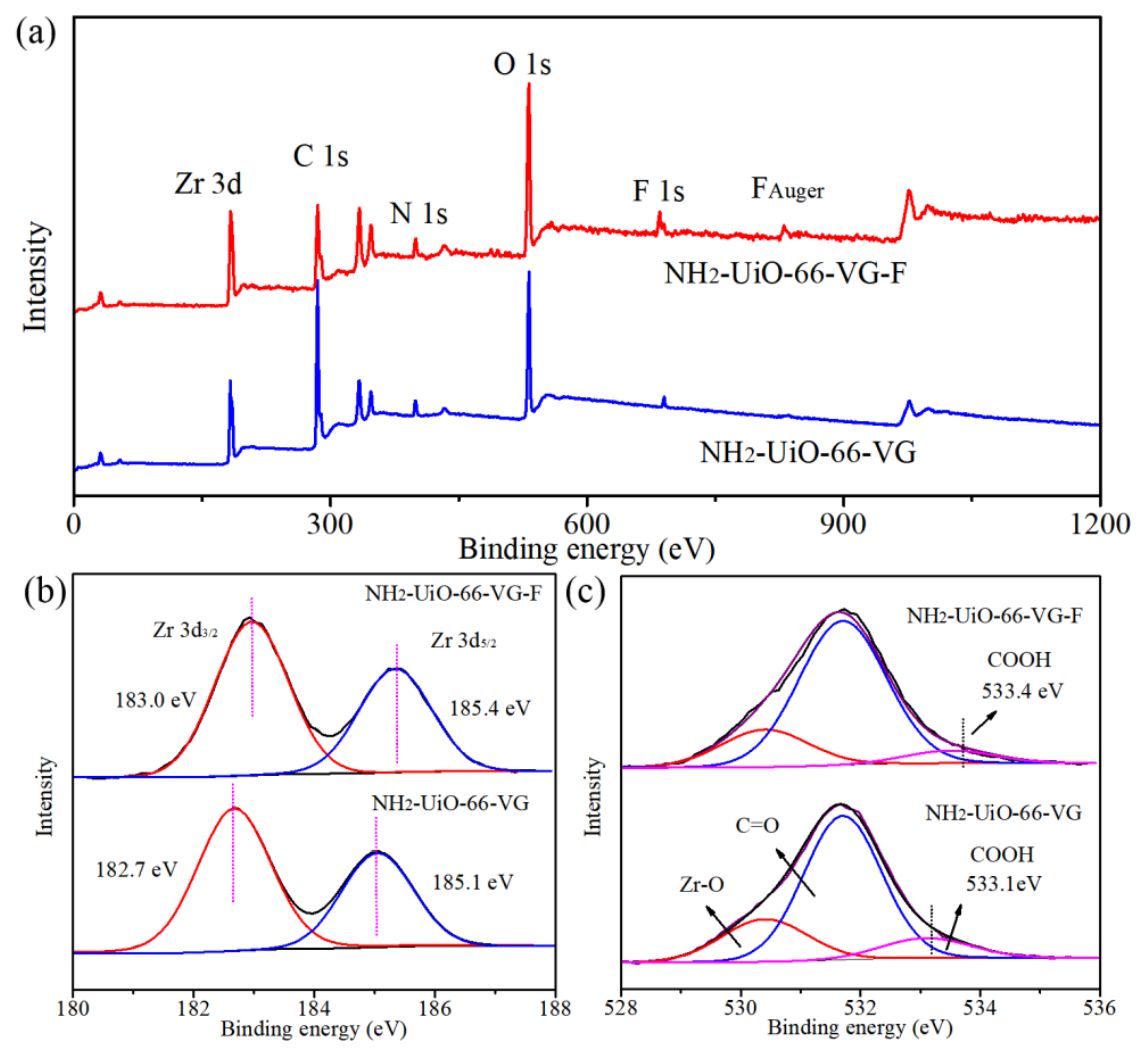

Figure S12. (a) XPS spectra of $\mathrm{NH}_{2}-\mathrm{UiO}-66-\mathrm{VG}$ and $\mathrm{NH}_{2}-\mathrm{UiO}-66-\mathrm{VG}-\mathrm{F}$. High-resolution (b) $\mathrm{Zr} 3 \mathrm{~d}$ and (c) O 1s XPS spectra of $\mathrm{NH}_{2}-\mathrm{UiO}-66-\mathrm{VG}$ and $\mathrm{NH}_{2}-\mathrm{UiO}-66-\mathrm{VG}-\mathrm{F}$. 


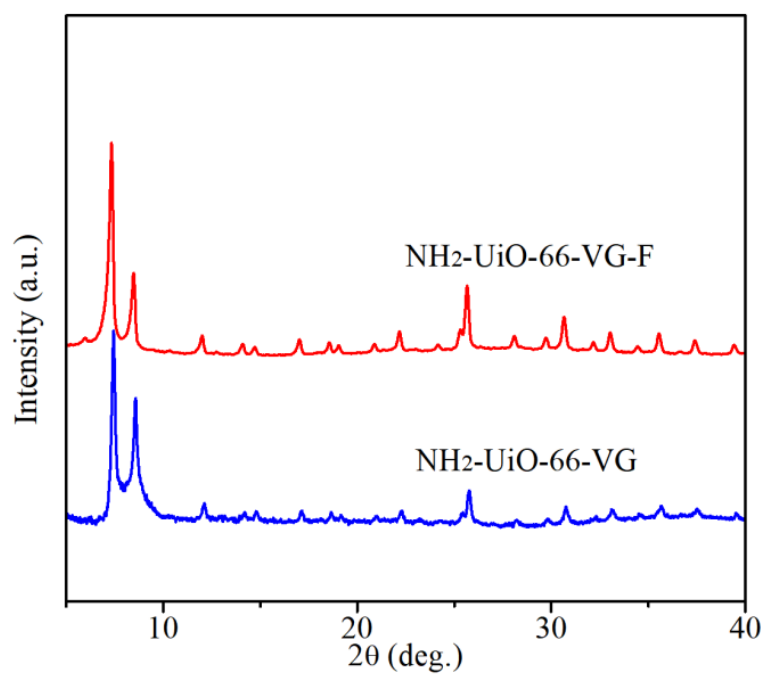

Figure S13. XRD patterns of $\mathrm{NH}_{2}-\mathrm{UiO}-66-\mathrm{VG}$ and $\mathrm{NH}_{2}-\mathrm{UiO}-66-\mathrm{VG}-\mathrm{F}$. 
Table S1. $\mathrm{S}_{\mathrm{BET}}$ and porous structures of $\mathrm{NH}_{2}-\mathrm{UiO}-66$ and $\mathrm{NH}_{2}-\mathrm{UiO}-66-\mathrm{VG}$.

\begin{tabular}{|c|c|c|c|}
\hline \multirow{2}{*}{ MOF } & \multirow{2}{*}{$\begin{array}{c}\mathrm{S}_{\mathrm{BET}} \\
\left(\mathrm{m}^{2} \mathrm{~g}^{-1}\right)\end{array}$} & \multirow{2}{*}{$\begin{array}{l}\text { Total pore volume } \\
\qquad\left(\mathrm{mL} \mathrm{g}^{-1}\right)\end{array}$} & \multirow{2}{*}{$\begin{array}{l}\text { Micropore volume } \\
\qquad\left(\mathrm{mL} \mathrm{g}^{-1}\right)\end{array}$} \\
\hline & & & \\
\hline $\mathrm{NH}_{2}$-UiO-66 & 1160 & 0.58 & 0.45 \\
\hline $\mathrm{NH}_{2}-\mathrm{UiO}-66-\mathrm{VG}-12$ & 1040 & 0.54 & 0.41 \\
\hline $\mathrm{NH}_{2}-\mathrm{UiO}-66-\mathrm{VG}-24$ & 1089 & 0.58 & 0.43 \\
\hline
\end{tabular}


Table S2. Gas adsorption properties of the prepared MOFs at $298 \mathrm{~K}$.

\begin{tabular}{|c|c|c|c|c|c|}
\hline \multirow[t]{2}{*}{ MOF } & \multicolumn{3}{|c|}{$\left(\mathrm{mL} \mathrm{g}^{-1}\right)$} & \multicolumn{2}{|c|}{ Selectivity } \\
\hline & $\mathrm{CO}_{2}$ & $\mathrm{CH}_{4}$ & $\mathrm{~N}_{2}$ & $\mathrm{CO}_{2} / \mathrm{N}_{2}$ & $\mathrm{CO}_{2} / \mathrm{CH}_{4}$ \\
\hline $\mathrm{NH}_{2}-\mathrm{UiO}-66$ & 54.4 & 12.2 & 4.0 & 13.2 & 4.4 \\
\hline $6 \mathrm{~h}$ & 45.7 & 12.1 & 4.8 & 8.9 & 3.6 \\
\hline $12 \mathrm{~h}$ & 43.4 & 13.0 & 5.2 & 8.0 & 3.2 \\
\hline $24 \mathrm{~h}$ & 51.0 & 10.4 & 3.3 & 14.5 & 4.7 \\
\hline $48 \mathrm{~h}$ & 44.5 & 10.9 & 3.1 & 13.4 & 4.0 \\
\hline
\end{tabular}


Table S3. Kinetic parameters of the adsorption of fluoride on MOFs.

\begin{tabular}{|c|c|c|c|c|c|c|c|}
\hline \multirow[b]{2}{*}{ MOFs } & \multirow{2}{*}{$\begin{array}{c}q_{e, \exp } \\
(\mathrm{mg} \\
\left.\mathrm{g}^{-1}\right)\end{array}$} & \multicolumn{3}{|c|}{ Pseudo-first-order rate law } & \multicolumn{3}{|c|}{ Pseudo-second-order rate law } \\
\hline & & $\begin{array}{c}k_{1} \\
\left(\min ^{-1}\right)\end{array}$ & $\begin{array}{c}q_{e, f i t t e d} \\
\left(\mathrm{mg} \mathrm{g}^{-1}\right)\end{array}$ & $R_{1}^{2}$ & $\begin{array}{c}k_{2} \\
\left(\min ^{-1}\right)\end{array}$ & $\begin{array}{c}q_{e, f i t t e d} \\
\left(\mathrm{mg} \mathrm{g}^{-1}\right)\end{array}$ & $R_{2}^{2}$ \\
\hline $\mathrm{NH}_{2}-\mathrm{UiO}-66$ & 42.57 & 0.0054 & 5.9524 & 0.7140 & 0.0228 & 40.6504 & 0.9369 \\
\hline $\mathrm{NH}_{2}-\mathrm{UiO}-66-\mathrm{VG}$ & 76.98 & 0.0117 & 33.7000 & 0.8947 & 0.0018 & 71.4285 & 0.9725 \\
\hline
\end{tabular}

The Pseudo-first-order kinetic model can be analyzed as follows:

$\ln \left(q_{e}-q_{t}\right)=\ln q_{e}-k_{l} t(3)$

Where the $k_{l}$ is the constant of the pseudo-first-order adsorption $\left(\mathrm{g} \mathrm{mg}^{-1} \mathrm{~min}^{-1}\right), q_{t}$ means the amount of fluoride adsorption at the certain time $\left(\mathrm{mg} \mathrm{g}^{-1}\right)$, and the $q_{e}$ represents the adsorption capacity at equilibrium $\left(\mathrm{mg} \mathrm{g}^{-1}\right)$.

The Pseudo-second-order kinetic model can be analyzed as follows:

$\frac{t}{q_{t}}=\frac{1}{q_{e}^{2} k_{2}^{2}}+\frac{t}{q_{e}}(4)$

Where the $k_{2}$ is the constant of the pseudo-second-order adsorption $\left(\mathrm{g} \mathrm{mg}^{-1} \mathrm{~min}^{-1}\right), q_{t}$ means the amount of fluoride adsorption at the certain time $\left(\mathrm{mg} \mathrm{g}^{-1}\right)$, and the $q_{e}$ represents the adsorption capacity at equilibrium $\left(\mathrm{mg} \mathrm{g}^{-1}\right)$. 
Table S4. Adsorption capacity of MOFs for fluoride removal.

\begin{tabular}{lccc}
\hline & Fluoride concentration & Adsorption capacity & \\
MOF & $\left(\mathrm{mg} \mathrm{L}^{-1}\right)$ & $\left(\mathrm{mg} \mathrm{g}^{-1}\right)$ & \\
\hline $\mathrm{NH}_{2}$-UiO-66-VG & 100 & 83.0 & This work \\
$\mathrm{NH}_{2}$-UiO-66 & 70 & 55.0 & 4 \\
MIL-96 & 50 & 31.7 & 5 \\
UiO-66 & & 41.4 & \\
MIL-53(Fe) & & 17.0 & 6 \\
CAU-6 & 40 & 24.2 & 7 \\
ZIF-7 & & 2.6 & \\
MOF-801 & & 40.0 & \\
\hline
\end{tabular}


Table S5. Langmuir and Freundlich isotherm modeling parameters of the adsorption of fluoride on MOFs.

\begin{tabular}{|c|c|c|c|c|c|c|}
\hline \multirow{3}{*}{ MOFs } & \multicolumn{3}{|c|}{ Langmuir } & \multicolumn{3}{|c|}{ Freundlich } \\
\hline & $q_{\max }$ & $K_{L}$ & & $K_{F}\left(\mathrm{mg} \mathrm{g}^{-1}\right)(\mathrm{L}$ & & \\
\hline & $\left(\mathrm{mg} \mathrm{g}^{-1}\right)$ & $\left(\mathrm{L} \mathrm{mg}^{-1}\right)$ & $\mathrm{R}_{\mathrm{L}}^{2}$ & $\left.\mathrm{mg}^{-1}\right)^{1 / \mathrm{n}}$ & $n$ & $\mathrm{R}_{\mathrm{F}}^{2}$ \\
\hline $\mathrm{NH}_{2}-\mathrm{UiO}-66$ & 29.15 & 9.5292 & 0.7141 & 16.6864 & 4.4208 & 0.9154 \\
\hline $\mathrm{NH}_{2}-\mathrm{UiO}-66-\mathrm{VG}$ & 41.84 & 7.7101 & 0.8515 & 23.5093 & 3.5410 & 0.9896 \\
\hline
\end{tabular}

The Langmuir isotherm model can be denoted as follows:

$\frac{C_{e}}{q_{e}}=\frac{1}{K_{L} q_{\max }}+\frac{C_{e}}{q_{\max }}(5)$

Where $K_{L}$ is the Langmuir adsorption constant $\left(\mathrm{L} \mathrm{mg}^{-1}\right)$, and $q_{\max }$ is the maximal adsorption capacity $\left(\mathrm{mg} \mathrm{g}^{-1}\right)$. And $C_{e}$ and $q_{e}$ represent the fluoride concentration and relative adsorption capacity at equilibrium $\left(\mathrm{mg} \mathrm{g}^{-1}\right)$.

The Freundlich isotherm model can be denoted as follows:

$\operatorname{Ln} q_{e}=\ln K_{F}+\frac{1}{n} \ln C_{e}(6)$

Where $K_{F}$ is the Freundlich adsorption constant $\left(\mathrm{mg} \mathrm{g}^{-1}\right)\left(\mathrm{L} \mathrm{mg}^{-1}\right)^{1 / n}$, and $n$ represents the heterogeneity factor of the adsorbent. And $C_{e}$ and $q_{e}$ represent the fluoride concentration and relative adsorption capacity at equilibrium $\left(\mathrm{mg} \mathrm{g}^{-1}\right)$. 


\section{References}

(1) Japas, M.; Sengers, J. L. Gas Solubility and Henry's Law Near The Solvent's Critical Point. AIChE J. 1989, 35, 705-713.

(2) Howarth, A. J.; Peters, A. W.; Vermeulen, N. A.; Wang, T. C.; Hupp, J. T.; Farha, O. K. Best Practices for the Synthesis, Activation, and Characterization of Metal-Organic Frameworks. Chem. Mater. 2017, 29, 26-39.

(3) Brunauer, S.; Emmett, P. H.; Teller, E. Adsorption of Gases in Multimolecular Layers. $J$. Am. Chem. Soc. 1938, 60, 309-319.

(4) Lin, K. Y. A.; Liu, Y. T.; Chen, S. Y. Adsorption of Fluoride to UiO-66- $\mathrm{NH}_{2}$ in Water: Stability, Kinetic, Isotherm and Thermodynamic Studies. J. Colloid Interface Sci. 2016, 461, 79-87.

(5) Zhang, N.; Yang, X.; Yu, X.; Jia, Y.; Wang, J.; Kong, L.; Jin, Z.; Sun, B.; Luo, T.; Liu, J. Al-1,3,5-Benzenetricarboxylic Metal-Organic Frameworks: A Promising Adsorbent for Defluoridation of Water with $\mathrm{pH}$ Insensitivity and Low Aluminum Residual. Chem. Eng. J. 2014, 252, 220-229.

(6) Zhao, X.; Liu, D.; Huang, H.; Zhang, W.; Yang, Q.; Zhong, C. The Stability and Defluoridation Performance of MOFs in Fluoride Solutions. Microporous Mesoporous Mater. 2014, 185, 72-78.

(7) Zhu, X.-H.; Yang, C.-X.; Yan, X.-P. Metal-Organic Framework-801 for Efficient Removal of Fluoride from Water. Microporous Mesoporous Mater. 2018, 259, 163-170. 